NBER WORKING PAPER SERIES

\title{
THE EFFECT OF NEW JERSEY'S \\ MINIMUM WAGE INCREASE ON FAST- \\ FOOD EMPLOYMENT: A RE-EVALUATION \\ USING PAYROLL RECORDS
}

David Neumark

William Wascher

Working Paper No. 5224

\section{NATIONAL BUREAU OF ECONOMIC RESEARCH 1050 Massachusetts Avenue \\ Cambridge, MA 02138 \\ August 1995}

We thank John Bound, William Dickens, Bruce Fallick, Harry Holzer, Lawrence Katz, Spencer Krane, John Strauss, Jeff Wooldridge, and seminar participants at Indiana University and IUPUI for helpful comments, and David Card and Alan Krueger for providing their data. We are grateful to Carlos Bonilla of the Employment Policies Institute (EPI), and to participating franchise owners and corporations, for providing us with the payroll data. The EPI is funded by business contributions and generally opposes minimum wage increases. However, the research described in this paper was conducted independently of the EPI, and neither author received any remuneration for conducting the research. The views expressed do not necessarily reflect those of the Employment Policies Institute, or of the Federal Reserve Board or its staff. This paper is part of NBER's research program in Labor Studies. Any opinions expressed are those of the authors and not those of the National Bureau of Economic Research.

(C) 1995 by David Neumark and William Wascher. All rights reserved. Short sections of text, not to exceed two paragraphs, may be quoted without explicit permission provided that full credit, including $(\mathcal{C}$ notice, is given to the source. 


\title{
THE EFFECT OF NEW JERSEY'S \\ MINIMUM WAGE INCREASE ON FAST- \\ FOOD EMPLOYMENT: A RE-EVALUATION \\ USING PAYROLL RECORDS
}

\begin{abstract}
We re-evaluate the evidence from Card and Krueger's (1994) New Jersey-Pennsylvania minimum wage experiment, using new data based on actual payroll records from 230 Burger King, KFC, Wendy's, and Roy Rogers restaurants in New Jersey and Pennsylvania. We compare results using these payroll data to those using CK's data, which were collected by telephone surveys. We have two findings to report.

First, the data collected by CK appear to indicate greater employment variation over the eight-month period between their surveys than do the payroll data. For example, in the full sample the standard deviation of employment change in CK's data is three times as large as that in the payroll data.

Second, estimates of the employment effect of the New Jersey minimum wage increase from the payroll data lead to the opposite conclusion from that reached by CK. For comparable sets of restaurants, differences-in-differences estimates using CK's data imply that the New Jersey minimum wage increase (of 18.8 percent) resulted in an employment increase of 17.6 percent relative to the Pennsylvania control group, an elasticity of 0.93 . In contrast, estimates based on the payroll data suggest that the New Jersey minimum wage increase led to a 4.6 percent decrease in employment in New Jersey relative to the Pennsylvania control group. This decrease is statistically significant at the five-percent level and implies an elasticity of employment with respect to the minimum wage of -0.24 .
\end{abstract}

David Neumark

Department of Economics

Michigan State University

East Lansing, MI 48824

and NBER
William Wascher

Board of Governors of the

Federal Reserve System

20th and Constitution, NW

Washington, DC 20551 


\section{$\underline{\text { I. Introduction }}$}

A recent study by David Card and Alan Krueger (1994) reported evidence that contrasts sharply with the conventional view that minimum wage increases reduce employment of lowwage workers. In particular, Card and Krueger (hereafter CK) surveyed fast-food establishments in New Jersey and Pennsylvania before and after the minimum wage in New Jersey rose from $\$ 4.25$ to $\$ 5.05$. A comparison of changes in employment in these two states provides a simple "differences-in-differences" test of the prediction that minimum wage increases reduce employment of affected workers. Contrary to this prediction, CK find "no evidence that the rise in New Jersey's minimum wage reduced employment at fast-food restaurants in the state ..." and even that "the increase in the minimum wage increased employment ..." (p. 792). Given the prominence that this study has received, both in support of recent proposals to increase the federal minimum and as evidence against the competitive labor market model, we believe that a careful re-evaluation of its results is of interest.

In this paper, we present new evidence based on actual payroll records from a sample of Burger King, Wendy's, Roy Rogers, and Kentucky Fried Chicken (KFC) restaurants in New Jersey and Pennsylvania, which overlaps substantially with CK's sample. We compare results using these payroll data to those using CK's data, which were collected by telephone surveys. We have two findings to report.

First, the employment data collected by CK appear to contain substantially more variation over the eight-month period between their surveys than do the payroll data. Overall, the standard deviation of employment change in CK's data exceeds that in the payroll data by a factor of three, and the 90th-10th centile difference exceeds that in the payroll data by a factor of 2.6. At a more disaggregated level (by restaurant chain, ownership, and state), the ratio of the standard deviation in CK's data to that in the payroll data is often above four. In our view, 
the much higher variability of employment change in the data collected by CK raises serious doubts about the quality of their data.

Second, estimates of the employment effect of the New Jersey minimum wage increase from the payroll data lead to the opposite conclusion from that reached by CK. Whereas CK's full sample, as well as the subset of their restaurants represented in the payroll data, point to a positive employment effect, the payroll data indicate a negative effect. For the subset of restaurants represented in the payroll data, CK's data imply that the New Jersey minimum wage increase (of 18.8 percent) resulted in an employment increase of 17.6 percent relative to the Pennsylvania control group, an elasticity of 0.93 . In contrast, differences-in-differences estimates based on the payroll data indicate that the New Jersey minimum wage increase led to a 4.6 percent decrease in employment in New Jersey relative to the Pennsylvania control group. This decrease is statistically significant at the five-percent level and implies an elasticity of employment with respect to the minimum wage of -0.24 . Sensitivity analyses of the differences-in-differences estimates with the payroll data indicate elasticities ranging from -0.18 to -0.27 , with the estimates statistically significant at the five- or ten-percent level. Thus, in contrast to CK's claim, the payroll data from the New Jersey-Pennsylvania minimum wage experiment are consistent with the prediction of the standard competitive model that minimum wage increases reduce employment of low-wage workers. ${ }^{1}$

\section{Card and Krueger's Results}

Panel A of Table 1 reports descriptive statistics and the main result from CK's data: On average, over a period of about eight months following New Jersey's minimum wage increase, employment at fast-food restaurants in New Jersey grew by relatively more full-time equivalents

${ }^{1} \mathrm{CK}$ conclude that the findings from the New Jersey-Pennsylvania experiment are "difficult to explain with the standard competitive model" (1994, p. 792). 
(FTE's) than in Pennsylvania. ${ }^{2}$ As shown in column (1), this difference arises from a small employment increase in New Jersey (0.66 FTE's) and a large employment decline in Pennsylvania (2.1 FTE's). Column (6) shows the differences-in-differences regression estimate with controls for chain and ownership (franchise vs. company-owned). The estimate indicates that employment in New Jersey grew by a statistically significant 2.78 FTE's relative to Pennsylvania, suggesting that minimum wages increase employment. The implied elasticity of employment with respect to the minimum wage is 0.70 .

The same rows also illustrate that there are some extremely large employment changes in CK's data. The largest employment decline is 41.5 FTE's, the largest increase is 34 FTE's, and the standard deviations of employment change are 8.4 in New Jersey and 10.8 in Pennsylvania. ${ }^{3}$ Given that the mean level of employment was 21.1 in the first survey and 21.3 in the second, the variability of employment change in CK's data is surprising, and provides a motivation for re-evaluating their minimum wage study using an alternative data source. ${ }^{4}$ III. The Payroll Data

\section{III.i. Data Collection}

By contacting franchise owners and corporate administrators, we obtained administrative payroll data for Burger King and KFC franchises, and Wendy's and Roy Rogers franchises and

${ }^{2}$ As in CK, full-time equivalents are defined as the number of full-time non-management employees, plus one-half the number of part-time non-management employees, plus the number of management employees. For reasons discussed below, the estimates reported here, and most of those discussed in the paper, are based on samples excluding restaurants that closed; consequently, the estimates in panel A differ slightly from those in CK's Table 3.

${ }^{3} \mathrm{~A}$ corresponding statistic appears in the footnotes to CK's Table 4, where they report that the standard deviation of employment change for the entire sample is $\mathbf{8 . 8}$.

${ }^{4}$ Evidence pointing to other problems with the data collected by CK--in particular, data on prices of menu items--is presented in Lavin (1995). 
company-owned restaurants, in over 80 percent of the zip codes in which CK's restaurants were located. We restricted attention to zip codes and restaurants--distinguished by chain and ownership--represented in CK's data; for example, we requested information on companyowned Roy Rogers restaurants in all zip codes in which CK had such restaurants. We used the Chain Operators Guide to identify all franchisees that had restaurants in any of these chains and were headquartered in Pennsylvania, New Jersey, or New York. ${ }^{5}$ We contacted each of these franchisees and requested that they retrieve their payroll records indicating the number of nonmanagement hours worked in the pay periods spanning the dates for each wave of CK's survey ${ }^{6}$ We made at least four attempts to elicit data from each franchisee, including telephone calls and faxed letters, unless they clearly indicated that they would not supply the data or informed us that they had no outlets in the zip codes covered in CK's data. Of the 45 franchisees contacted, 17 supplied data, eight declined to supply data, 12 did not return repeated messages or respond to faxes, and eight indicated they had no outlets in the zip codes in which we were interested. ${ }^{7}$ Contact was also made with payroll administrators at each of the parent corporations, to attempt to obtain data on company-owned restaurants. Roy Rogers and Wendy's supplied data. Each of the cooperating franchisees or parent corporations submitted data on the total number of hours worked by non-management employees. To obtain data more comparable to CK's data, we then converted the hours data into full-time equivalent employees

${ }^{5}$ In principle, a franchisee located in any state could have outlets in New Jersey or Pennsylvania. We assumed that we would cover most outlets by surveying these three states.

${ }^{6}$ Because we cannot uniquely identify the restaurants in CK's data set (and because CK's data set does not include the date of the interview in the first wave of the survey), this is the closest we can come to matching up the two data sources.

${ }^{7}$ One of these 45 franchisees was not listed in the Chain Operators Guide as headquartered in Pennsylvania, New Jersey, or New York, but was mentioned to us in conversation with other franchise owners as owning a relatively large number of restaurants in New Jersey. 
(FTE's) assuming a full-time workweek of 35 hours.

The Employment Policies Institute (EPI) was involved in the initial data collection, and supplied us with data on the 71 Burger King and Wendy's franchises used in the earliest version of this study. Because the EPI has a stake in the outcome of the minimum wage debate, we took a number of steps to confirm the validity of the data supplied by the EPI. First, we spoke with each franchise owner who supplied data and verified that they provided numbers from their payroll databases. Frequently, the franchisees reported obtaining the data directly from ADP, a New Jersey-based payroll processing firm. ${ }^{8}$ Second, we requested and received signed statements from each franchisee attesting to the veracity of their data; these statements included a transcription of the actual payroll data. Finally, to protect against the possibility that EPI withheld data on restaurants for which the results were consistent with CK's results, we contacted every franchisee in the Chain Operators Guide, to verify that franchisees had not supplied data to the EPI which were not subsequently supplied to us. As a result of the combination of these procedures, we are confident that the data are valid. Nonetheless, to avoid conflicts of interest we subsequently took over the data collection effort from EPI, so that the remaining data came from the franchisees or corporations directly to us. ${ }^{9}$

CK's data set does not include a unique restaurant identifier (such as an address), so we

\footnotetext{
${ }^{8}$ We cannot use ES-202 records to verify the data, because these are reported by company, not establishment, and many franchisees own multiple restaurants, sometimes in more than one chain.

${ }^{9}$ The only exception is that EPI also obtained corporate Wendy's data on nine restaurants, which came with a signed letter from the Senior Vice President for Human Resources attesting to the veracity of the data. We should also point out that the evidence of negative minimum wage effects in the payroll data did not change as the data we collected were added to the data set. Using only the 71 observations supplied by the EPI from the earliest version of this study, the regression estimate of the elasticity of employment with respect to minimum wages was 0.25 , significant at the ten-percent level. In the current version of the paper, the corresponding elasticity is -0.24 , significant at the five-percent level.
} 
were unable to match up individual units. However, their data set does include the first three digits of the zip code (the zip code sectional area) in which each surveyed restaurant is located, enabling us to match units by location. We attempted to identify zip code areas in which we collected data from all franchises (or company-owned restaurants) in a chain, so that we could obtain a set of zip code areas in which all of the restaurants included in CK's data set also appear in our data set. This is not important for estimating employment effects of minimum wages, but is useful for a fairer comparison of the variability of employment change in the two data sources. For the company-owned restaurants, we obviously have all of the corresponding restaurants included in CK's data set. For the franchises, we identified zip code areas in which we obtained data on all franchises in a chain based on information on franchise agreements supplied by franchisees (which might specify, for example, that one or two franchisees had all franchises in the region.) We then checked on this information by verifying that no other franchisee reported restaurants in a chain and zip code for which we had been told we had complete coverage of restaurants. In only two cases did a contradiction arise (for Burger King franchises in two Pennsylvania zip codes), and we eliminated these two zip code/chain pairs from the subsample for which we have complete data. In the final analysis, we were able to obtain data on either all franchises or all company-owned restaurants in a chain for 24 zip code/chain/ownership combinations (seven in Pennsylvania and 17 in New Jersey) and data on some franchises for an additional 24 zip code/chain/ownership combinations. ${ }^{10,11}$

\footnotetext{
${ }^{10}$ For franchises, the data collection efforts focused on current franchisees in the zip code area. Current franchisees supplied data on all restaurants in operation at the time of CK's study, as did the corporations. However, we do not have information on franchisees that may have been operating at the time of the study but subsequently closed.

${ }^{11}$ As an additional check on the validity of the payroll data, we verified that, for the zip code/restaurant combinations for which we have data on all restaurants in the zip code, whenever CK's data indicated a restaurant closing, the payroll data also indicated a restaurant
} 


\section{III.ii. Limitations and Representativeness of the Payroll Data}

Table 2 provides a comparison of restaurants in CK's data to those in the payroll data.

Panel A shows the number of each type of restaurant in CK's full sample and the number of zip code areas covered. Panel B shows similar numbers for the subset of CK's restaurants (distinguished by chain, ownership, and zip code area) that are represented in the payroll data; we refer to this subset as the "sampled universe." Finally, Panel C reports the same information for the payroll data. Obviously, we have a non-representative sample of the restaurants in CK's data, in terms of chain, ownership, and zip code area. In some cases, we have more restaurants of a particular type than do CK, and in some cases we have less. Also, our data are from a subset of the zip code areas represented in CK's data. ${ }^{12}$ Below, we will consider the sensitivity of estimated employment effects to differences between the restaurants represented in the two data sources. In addition to this limitation, we were able to obtain data only on non-management employees, whereas $\mathrm{CK}$ also had data on managerial employment.

To consider the extent to which these two limitations of the payroll data may influence the results, we compare descriptive statistics and results in CK's full sample to those obtained from CK's sample when we limit the employment definition to non-management FTE's, and

closing. There were two such cases. (CK were careful to document restaurant closings, so this is one dimension on which we can use their data to assess the reliability of our data.)

${ }^{12}$ Table 2 indicates that $\mathrm{CK}$ have Roy Rogers company-owned restaurants in three more New Jersey zip code areas than do we (16 vs. 13). For two of the three zip code areas in which CK report such restaurants, Roy Rogers indicates no company-owned restaurants. For the third, Roy Rogers indicates one such restaurant that closed by November 1992, while CK report two such restaurants, both of which remained open. In addition, Table 2 shows that in CK's data there are four Wendy's restaurants in New Jersey classified as company-owned. However, according to Wendy's Senior Vice President for Human Resources, at the time of the study there were no company-owned Wendy's restaurants in New Jersey. Since CK interviewed a manager or assistant manager, it is possible that they obtained an incorrect classification of the ownership status of some restaurants from their telephone survey. 
when we restrict attention to the zip codes/restaurants for which payroll observations were available. This evidence is presented in panels B-D of Table 1. In panel B, we restrict attention to non-management employment as measured in CK's data. The variability of employment change and the regression estimate of the minimum wage effect on employment are very similar to what is reported in panel $\mathrm{A}$, using total employment. Thus, the restriction to non-management employment seems unimportant. ${ }^{13}$

In panel $\mathrm{C}$, we report results using the sampled universe of CK's observations. For comparison, in Panel D we also report results using the subset of CK's observations not represented in the payroll data. With respect to the variability of employment change, the restaurants in the sampled universe in Pennsylvania exhibit considerably higher variability than the restaurants in the nonsampled universe, while those in New Jersey exhibit similar (if slightly higher) variability. This suggests that a simple comparison of the variability of employment change in the payroll data with that in the corresponding sampled universe in CK's data probably overstates the variability of employment change in CK's data. However, this overstatement is likely to be considerably less than indicated by the differences between the Pennsylvania figures in panels $\mathrm{C}$ and $\mathrm{D}$ alone, because there are many more observations in New Jersey in CK's data. A more accurate comparison can be obtained by combining the Pennsylvania and New Jersey restaurants in CK's data. In this case, the standard deviation of employment change is 9.6 in the sampled universe, and 7.8 in the nonsampled universe, while the 90 th-10th centile range is 21.0 in the sampled universe, and 16.6 in the nonsampled universe.

Turning to the influence of the sampling limitations associated with the payroll data on

${ }^{13} \mathrm{CK}$ also report, in row 3 of their Table 5, that excluding managers has no effect on their conclusions. 
the estimated minimum wage effects, the figures in column (1) in panels $C$ and $D$ indicate that, to some extent, we have sampled from Pennsylvania restaurants in which employment declines were larger (3.0 vs. 1.6), and from New Jersey restaurants in which employment growth was higher $(0.90$ vs. 0.22$)$. However, in both the sampled and nonsampled universe, relative employment growth in New Jersey was considerably higher; this is reflected in the estimated employment effects in column (6) of 3.39 and 1.62, respectively. Moreover, these estimates indicate that we have, if anything, sampled from a subset of the restaurants in CK's data for which the data indicate larger employment increases resulting from the higher minimum wage. Consequently, if (as reported below) the payroll data indicate negative, rather than positive, employment effects, it is reasonable to believe that a similar conclusion would be reached from payroll data drawn from all of the restaurants in CK's data set. Nonetheless, it will still be most instructive to compare results obtained from the payroll data to results obtained from the sampled universe of CK's data set--specifically, Burger King and KFC franchises, and Wendy's and Roy Rogers franchises and company-owned restaurants, in the zip code areas represented in the payroll data.

IV. Comparisons of the Variability of Employment Change in the Payroll and Telephone Survey Data

Table 3 provides a comparison of CK's data and the payroll data, broken down by the type of restaurant and the state in which the restaurant is located. ${ }^{14}$ Panel A reports on zip code

\footnotetext{
${ }^{14}$ In order to provide a fair comparison of variability in the two data sources, when we obtained data for more than one payroll period within the time frame of CK's surveys, we randomly selected data for one period. Averaging over multiple pay periods would tend to decrease the variability of employment change in the payroll data, compared with CK's data. Later, when we examine the implied minimum wage effects using the payroll data, we obtain the most accurate estimates possible by averaging over data for multiple payroll periods to estimate employment levels. We also exclude, as noted earlier, the restaurants in CK's data set and in the payroll data that closed by the second wave of the survey. Given that it is
} 
areas for which we have complete data--that is, data from all franchises or company-owned restaurants in a chain. Thus, the observations in CK's data ought to appear in the payroll data for these zip code/restaurant combinations, although the reverse need not hold. As indicated in the last two rows of panel $\mathrm{A}$, the payroll data indicate substantially less variation in employment over time than do CK's data: the standard deviations of employment change in CK's data are 8.0 for Pennsylvania and 6.9 for New Jersey, versus 2.8 and 3.0 in the payroll data. The 90th10th centile differences are also considerably smaller in the payroll data. Moreover, when disaggregated by type of restaurant and state, the measures of dispersion are always considerably higher in CK's data than in the payroll data; for example, the standard deviations are higher by a factor ranging from 2.3 to 5.3 .

As shown in panel B, the variability of employment change also is much higher in CK's data than in the payroll data for the zip code areas in which we have data on only some franchises, with the difference particularly pronounced for Pennsylvania. Finally, in panel C we report similar statistics for all of the observations in panels A and B combined, which provides the simplest comparison of variability in the two data sources. The standard deviation of employment change is 9.6 in CK's data, versus 3.2 in the payroll data, while the 90th-10th centile difference is 21.0 in CK's data, versus 7.9 in the payroll data.

The greater variability in CK's data is not driven by one or two outliers. Figure 1 shows histograms for the initial employment levels and employment changes in the two data sources for the restaurants in zip code areas in which we have complete data. The upper lefthand panel shows the distribution of initial employment levels in CK's data, while the lower

appropriate to set second-wave employment to zero when a restaurant closes (as CK do), dropping restaurants that closed avoids the possibility that the differences in estimates of employment variability in the two data sources arise because of differences in the number of closed restaurants. 
left-hand panel shows the same distribution for the payroll data. The initial employment levels in the payroll data are more clustered in the 10-25 range and exhibit fewer extremely large values. The middle panels show the same histograms for employment levels at the time of the second survey. Again, CK's data exhibit more employment variability than the payroll data. Finally, the two right-hand panels show the histograms for employment changes. Here the contrast is most striking, with the employment changes in CK's data much more dispersed than in the payroll data. Figure 2 displays similar histograms for the full payroll data set and the observations in the sampled universe of CK's data set. Again, employment change is much more dispersed in CK's data than in the payroll data.

One potential explanation of the greater variability of employment change in CK's data relative to the payroll data is that the payroll data measure hours (which we convert to FTE's), whereas CK's data measure number of employees. Although in principle the variability of employment change measured these two ways could differ, we are skeptical of this explanation for two reasons. First, if there are fixed costs to hiring and firing workers, we would expect hours to be more variable than employment, and thus employment change in the payroll data should, if anything, be more variable. Second, we are able to obtain a direct comparison of the variability of employment change--with employment measured as the number of employees--for a subset of observations in the payroll data for which respondents happened to supply data on non-management employment (even though we did not ask for these data). We can then extract the subsample of CK's data, distinguished by chain, ownership, and zip code area, from which these observations in the payroll data are drawn, and compare the variability of the change in number of employees in the two data sources. For the 52 restaurants in the payroll data with information on employment levels, the standard deviation of the change in the number of workers employed is 4.3. In CK's data, for the 80 restaurants in the corresponding sampled 
universe, the standard deviation is 11.9. Thus, even when we use the same employment measure, we find that the variability of employment change in CK's data is nearly three times that in the payroll data.

Instead, we suspect that the high variability of employment change in CK's data arises because their survey questions eliciting employment levels were imprecise. CK's interviewer first verified that they were speaking with a manager or assistant manager. They then asked "How many full-time and part-time workers are employed in your restaurant, excluding managers and assistant managers?" Survey respondents were not given any time period over which to define employment, and their answers may well have ranged from employment on the shift during which the telephone survey took place to employment over an entire payroll period. Moreover, because different managers may have been interviewed in the two waves of the survey, there is no reason to believe that the responses in the first and second waves are based on the same "definition" of employment, which may explain the much higher variability of employment change. ${ }^{15}$ In contrast, the payroll data provide total hours worked for a welldefined payroll period (which is specified as either weekly, bi-weekly, or monthly), on a consistent basis for the two survey periods, and should therefore be more reliable.

\section{Comparisons of Estimated Employment Effects in the Payroll and Telephone Survey Data}

\section{V.i. Basic Results}

The comparisons in Table 3 also indicate that the average employment changes by state differ in the two data sources. For example, in panel A CK's data indicate an average employment decline of 4.8 FTE's in Pennsylvania, while the payroll data show an average employment decline of 0.1 FTE's. For New Jersey, CK's data indicate average employment

\footnotetext{
${ }^{15}$ Welch (1995) provides a detailed critique of CK's survey instrument.
} 
growth of 0.3 FTE's, while the payroll data indicate an average employment decline of 0.6 FTE's. Because CK's statistical experiment identifies the effect of minimum wages on employment from the difference between employment growth in New Jersey and Pennsylvania, these differences in average employment growth in the two data sources suggest that the payroll data will show much different employment effects of the New Jersey minimum wage increase from that estimated by CK.

Table 4 reports the fundamental results from our re-evaluation of the New JerseyPennsylvania minimum wage study using the payroll data. The first row reports the differences-in-differences estimates based on the means (column (1)) and from a regression controlling for chain and ownership (column (2)), using CK's data on non-management employment for all Burger King and KFC franchises, and Wendy's and Roy Rogers franchises and company-owned restaurants, regardless of zip code area. For this sample, CK's data indicate a significant positive employment effect of minimum wages. The mean estimate indicates that employment in New Jersey grew by 3.18 FTE's relative to Pennsylvania, while the regression estimate is 3.15 ; both estimates are statistically significant at the five-percent level. Columns (3) and (4) show the implied elasticity of employment with respect to the minimum wage from the regression estimate and the corresponding percent increase in employment. The implied elasticity is 0.90 , and the implied increase in employment is 16.9 percent (the minimum wage rose by 18.8 percent). ${ }^{16}$ The second row of Table 4 restricts attention to restaurants in the zip code areas for which we have payroll data, or the sampled universe in CK's data. In this sample, the estimated minimum wage effect on relative

${ }^{16}$ The high elasticity is partly attributable to the restrictions imposed on the sample, as outlined in Table 1. For the total change in FTE's for all units, the elasticity implied by the estimates in Table 1 is 0.70 . Looking at non-management employment only, the elasticity rises to 0.88 . 
employment growth in New Jersey is 3.92 from the means and 3.39 from the regression, both of which are significant at the ten-percent level. The regression estimate implies an elasticity of 0.93. These extraordinarily high elasticity estimates also suggest that something is awry with CK's data.

The third row reports the results we obtain using the payroll data instead of CK's data. In contrast to CK's results, the payroll data indicate that relative employment decreased in New Jersey. The mean differences-in-differences estimate shows a relative employment decline of 0.98 FTE's, and the regression estimate indicates a decline of 0.75 FTEs; both estimates are significant at the five-percent level. The implied elasticity of employment with respect to minimum wages (based on the regression) is -0.24 , toward the upper end of the range of disemployment effects in other minimum wage studies (e.g., Brown, et al., 1982, and Neumark and Wascher, 1992). Of course, it is not clear what elasticity we ought to expect for fast-food employment, as estimates from existing research generally refer to overall employment effects for teenagers or young adults. ${ }^{17,18}$

To this point, we have used the payroll data set in which we randomly selected one payroll record within the periods in which CK's surveys were conducted, in order to provide the fairest comparison of the variability of employment in the two data sources. However, we

\footnotetext{
${ }^{17} \mathrm{CK}$ argue that if the conventional labor demand model is correct such estimates should provide a lower bound for minimum wage effects on fast-food employment, presumably because a relatively large proportion of fast-food workers earn at or near the minimum wage. However, the minimum wage effect will also depend on the elasticity of substitution between labor and other inputs (or between low-skill and high-skill labor). We are not aware of any estimates of the relative magnitudes of the elasticity of substitution in this industry.

${ }^{18}$ Note also that the adjusted- $\mathrm{R}^{2}$ jumps from 0.02 or 0.03 to about 0.45 , reflecting the considerable sampling error in CK's data. However, the increment to the adjusted- $R^{2}$ is attributable to differences in employment growth across chains that are strongly significant in the regressions using the payroll data, but not CK's data, rather than stronger employment effects of minimum wages in the payroll data.
} 
can, in principle, obtain a more precise estimate of employment in these periods by averaging across all possible payroll records within CK's survey periods. ${ }^{19}$ Estimates using these averages are reported in the last row of the table, and in our view provide the best estimates from the payroll data. In this case, the estimated disemployment effects of the New Jersey minimum wage increase are similar $(-0.92$ and -0.76$)$ to those in the previous row, with slightly smaller standard errors. The regression estimate implies an elasticity of employment with respect to the minimum wage of -0.24 , and an employment loss of 4.6 percent in New Jersey relative to Pennsylvania. ${ }^{20}$

One obvious question that arises from Table 4 is why supposedly random measurement error in CK's data should lead to a differently-signed estimate of the employment effect of the New Jersey minimum wage increase. What the results suggest, of course, is that the measurement error is not random across states. In particular, CK's survey appears to have overstated employment growth in New Jersey and overstated the employment decline in Pennsylvania. ${ }^{21}$

\footnotetext{
${ }^{19} \mathrm{We}$ have data on multiple payroll periods for 38 percent of the observations in the payroll data.

${ }^{20}$ We also tried weighting by the number of payroll records used in constructing these averages. This had little influence on the estimates.

${ }^{21}$ One possibility that has been suggested (by William Dickens) is that CK's data may detect undocumented workers receiving cash wages, and presumably paid less than the minimum wage, while the payroll data probably only cover documented workers. If this were true, then the payroll data might overestimate the decline in total employment, if New Jersey employers substituted undocumented for documented workers in response to the minimum wage increase. We are unaware of any direct information on undocumented workers in the fast-food industry. However, for the subsets of the two data sources for which we can compare numbers of employees, the mean employment level in New Jersey restaurants is 32.1 in CK's data and 28.4 in the payroll data, and so we cannot rule out the possibility that some undocumented workers have been counted in CK's data.

Of course, the difference in results in the two data sources would have to be driven by an increase in undocumented workers in New Jersey restaurants that was picked up in CK's data
} 


\section{V.ii. Wage Gap Regressions}

$\mathrm{CK}$ also present results in which they regress employment changes on the percentage difference between the minimum wage and the starting wage initially paid by the restaurant, with this "wage gap" variable set to zero for Pennsylvania restaurants. This experiment continues to identify minimum wage effects off of the difference in employment growth between New Jersey and Pennsylvania, but adds information on the extent to which the minimum wage increase would have raised starting wages in New Jersey. In contrast to the conventional prediction, CK find a positive effect of this wage gap measure. We do not have information on the starting wages paid at the restaurants on which we have payroll data and therefore cannot assess this evidence as directly as we can address CK's differences-in-differences results. ${ }^{22}$ However, we can estimate the average starting wage by restaurant type (distinguished by chain and ownership) and zip code area using CK's data, match this average to corresponding establishments in the payroll data, and estimate CK's specification. Because we do not have the actual starting wages, we do not regard our evidence on this point to be as reliable as the direct FTE comparisons in Table 4. Nonetheless, it is of interest to check whether the same reversal of the sign of the minimum wage effect occurs in this statistical experiment. We can also obtain a more comparable set of results with CK's data by estimating the wage gap regression

but not the payroll data. However, the average changes in employment in these restaurants are not very different ( 3.75 in CK's data, and 3.16 in the payroll data) and, although based on very small samples, do not support the hypothesis that undocumented workers explain the different results. Finally, we would note that if minimum wage increases fail to reduce (or even increase) employment because they lead to substitution toward undocumented workers earning less than the minimum wage, then any arguments in favor of raising the minimum based on CK's findings are weakened, because many workers employed after the minimum wage increase would earn less than the new minimum, and perhaps also less than the old minimum.

${ }^{22}$ We chose not to request data on starting wages in order to maximize the likelihood that franchisees and parent corporations would supply the more important hours data. 
with their sample, but using the same average wage to construct the wage gap that we are forced to use in the payroll data.

The results are reported in Table $5 .{ }^{23}$ We begin by reporting CK's regression for the sample of Burger King and KFC franchises, and Wendy's and Roy Rogers franchises and company-owned restaurants, using the actual starting wage to construct the wage gap measure. The estimated coefficient on the wage gap is 22.3 , and the implied elasticity with respect to the minimum wage is $0.72 .{ }^{24}$ The second row restricts attention to the sampled zip code areas, while continuing to use the actual starting wage. The estimated elasticity of 0.73 is similar to that in the first row. The third row shows the effect of using the mean starting wage in the zip code area (for the corresponding type of restaurant) to construct the wage gap measure--as we have to do with the payroll data--instead of using the actual reported starting wage. The point estimate (27.4) is larger, and--as we would expect--the standard error increases. The fact that the estimated coefficient on the wage gap remains positive in this case indicates that differences in the results from using the payroll data (discussed below) are not attributable to the restriction to a subset of zip code areas and restaurant types or to the use of the mean starting wage in the zip code area to construct the wage gap measure.

Next, we move on to the results from the payroll data. The fourth row of the table reports estimates of the same specification with the payroll data, using the average of employment levels in the payroll records. In contrast to the results obtained with CK's data,

\footnotetext{
${ }^{23}$ From this point on, we show results for the averaged payroll data; results were virtually the same using the randomly selected payroll observations.

${ }^{24}$ These estimate are considerably larger than those reported in column (iii) of their Table 4 . This owes to the restriction to particular types of restaurants. If we include all restaurants except those that closed by the time of CK's second survey, the estimated coefficient (standard error) is $16.6(5.9)$, very close to their reported estimate.
} 
the estimated coefficient on the wage gap variable is negative, with a t-statistic of 1.5 . The implied elasticity is -0.13 , smaller than the elasticity obtained from the differences-indifferences comparison; this may be partly attributable to measurement error associated with our proxy for the wage gap. Finally, in the last row we also add to this specification a dummy variable for New Jersey, so that the wage gap coefficient is identified solely off of the withinNew Jersey variation. In this case, the estimated coefficient of the wage gap variable turns positive, with a t-statistic below one; in contrast, the estimated coefficient of the New Jersey dummy is negative and significant at the five-percent level. The overall minimum wage elasticity from this specification is -0.24 , in line with the elasticities reported in Table 4 .

\section{V.iii. Sensitivity Analyses}

In Table 6, we report on some sensitivity analyses to probe the robustness of the differences-in-differences results using the payroll data reported in Table 4. First, in panel A we report results when we include the closed restaurants in both data sources, with secondperiod employment set to zero. The results using CK's data are similar to those obtained when the closed restaurants were dropped..$^{25}$ With the payroll data, the estimated employment effect using the means $(-0.88)$ is slightly smaller than the corresponding estimate in Table $4(-0.92)$, and is significant only at the ten-percent level. The regression estimate is also slightly smaller than in Table $4(-0.70$ vs. -0.76$)$, and is also only significant at the ten-percent level.

In panel $\mathrm{B}$, we instead include only those closed restaurants that appear to be common to both data sources (i.e., they appear in the same zip code area for the same type of restaurant). There are two such restaurants. The rationale for doing this is to avoid sensitivity of the results to the number of closings in each data set, given that restaurant closings entail large

\footnotetext{
${ }^{25}$ Throughout this table, we show only the results for the sampled universe; the results were similar using CK's full sample.
} 
employment swings. As panel B shows, the estimates using CK's data are little changed. For the payroll data, this more restrictive rule for including closed restaurants yields negative estimated minimum wage effects on employment that are slightly stronger than those in Table 4 and are statistically significant at the five-percent level; the elasticity from the regression estimate is -0.27 .

Next, we consider differences-in-differences specifications that use the proportional change in employment as the dependent variable, weighting by the initial level of employment. ${ }^{26}$ As panel $\mathrm{C}$ of Table 6 shows, the results using CK's data are similar to those obtained using the change in levels. The estimated minimum wage effects are positive and significant at the fivepercent level, with an elasticity from the regression estimate of 0.88 . With the payroll data, we obtain an estimate from the means of -0.061 (significant at the five-percent level) and an estimate from the regression of -0.034 (significant at the ten-percent level), with an elasticity of $-0.18 .^{27}$

In panel D we explore the influence of the different representation of restaurants in the payroll data and in CK's data. In particular, we weight the observations in the payroll data to correspond to the restaurants in the sampled universe of CK's data set. We calculate separate weights by chain, ownership, and state. For example, referring back to Table 2, Burger King

${ }^{26} \mathrm{As} \mathrm{CK}$ explain, the weighted proportional change regressions should be comparable to the change in levels regressions because "the proportional change in average employment is an employment-weighted average of the proportional changes at each store" (p. 782).

${ }^{27}$ We constructed the dependent variable as the change in employment divided by the initial level of employment (whereas CK divided by the average of employment in the two waves of the survey) because conditional on the initial employment level, dividing by the average attenuates the employment change. When we divided by the average of the two employment levels to construct the percent change in employment, the regression estimate (standard error) was $-0.030(0.021)$. When we did not weight by initial employment, the regression estimate was $-0.031(0.021)$. 
franchises in Pennsylvania are overrepresented in the payroll data by a factor of $31 / 20$. We thus apply a weight of $20 / 31$ to observations on these units. The weighted estimates indicate similar disemployment effects of minimum wages to the unweighted estimates in Table 4; the elasticity from the regression estimate, which is significant at the five-percent level, is -0.27 .

Finally, because we obtained data on multiple restaurants owned by franchisees (or corporations), we estimate random effects models that allow for non-independent errors among restaurants with the same owner. ${ }^{28}$ These estimates, reported in panel $\mathrm{E}$ of Table 6 , indicate a slightly smaller negative minimum wage effect on employment $(-0.64)$, and, as we would expect, a larger standard error. However, the estimated disemployment effect remains significant at the ten-percent level. Moreover, an LM test indicates that we cannot reject the hypothesis of no common error across restaurants with the same owner, suggesting that the Table 4 estimates are preferable (i.e., consistent and more efficient) to the random effects estimates.

\section{V.iv. Summary}

Using the payroll data, all of the variations of the basic differences-in-differences specifications yield estimated minimum wage effects on employment that are negative and significant at the five- or ten-percent level. In contrast, for nearly every estimation that CK report corresponding to a specification that we estimate, the estimated minimum wage effect on employment is positive and significant at the five- or ten-percent level. ${ }^{29}$ Thus, the evidence from the payroll data is strongly at odds with the evidence reported by CK.

\footnotetext{
${ }^{28}$ Because CK's sample was drawn from telephone books, they could not identify common owners (except for their company-owned restaurants).

${ }^{29}$ The only exceptions are the unweighted percent change specifications, which, as CK note, should not be expected to replicate the elasticities obtained from the levels regressions. In these specifications, CK's results indicate positive but insignificant employment effects.
} 


\section{Alternative Evidence}

Given the striking differences between the two data sources in the estimates of mean employment growth over the February to November 1992 period, it would be useful to compare these estimates with either sample-based estimates or administrative records from standard government data collection programs. The most obvious source of data in this regard is the BLS series on establishment employment. Unfortunately, however, the BLS does not produce employment counts specifically for fast-food restaurants, but instead provides numbers on employment in all eating and drinking places (SIC 58); these data are available at the national, state, and county level. ${ }^{30}$

The BLS data on employment growth in eating and drinking establishments from February to November 1992 are shown in Table 7, along with similar figures for other years and the comparison figures on the percentage changes in employment from CK's data and the payroll data. The first set of columns in panel A presents state-level data separately for New Jersey and Pennsylvania from the BLS-790 program. The second set of columns shows the same data from the ES-202 program, while the third set of columns includes only those Pennsylvania counties in zip codes covered by CK's data. Technically, both the BLS-790 data and the ES-202 data are based on unemployment insurance tax records through the first quarter of 1994. However, there are differences between the two data sources that reflect technical adjustments to the BLS-790 data to make the data more comparable over time. In this respect, the BLS does not consider the ES-202 data to provide valid time-series data, so the BLS-790 data on employment growth might be regarded as more reliable for this analysis.

\footnotetext{
${ }^{30}$ Although monthly data exist for each of these geographic levels of disaggregation, the BLS only publishes employment data on eating and drinking places at the national level. State data from the BLS-790 program are available from the LABSTAT database, while state and county data from the ES-202 program are available upon request from the BLS.
} 
Focusing on 1992, there are two things of note. First, the difference between employment growth in New Jersey and Pennsylvania is quite small over the February to November period, and in two of the three data sources, New Jersey shows slightly faster growth than Pennsylvania, a fact that, at first glance, might be taken to be more consistent with CK's data than with the payroll data. However, the second point to note is that in neither state are the employment growth figures in the BLS data close to those in CK's data (reported in panel B), or in the payroll data (reported in panel C). Most strikingly, the BLS data do not show the sharp employment decline in Pennsylvania that is exhibited in CK's data; this decline in Pennsylvania is the principal difference between CK's data and the payroll data and drives their results. These differences between the BLS data and the fast-food data suggest that movements (which may be seasonal) in the non-fast-food component of the eating and drinking SIC dominate those in the fast-food component. ${ }^{31}$ This, in turn, suggests that the data on eating and drinking places are not particularly informative with regard to the reliability of either CK's data or the payroll data. ${ }^{32}$

Nonetheless, the BLS employment data for eating and drinking places are of independent interest because they provide an alternative estimate of minimum wage effects for an industry

\footnotetext{
${ }^{31}$ According to the 1992 Census of Retail Trade, establishments classified as refreshment places where customers order and pay at the counter but with inside seating (of which fast-food restaurants are only a part) comprise about 20 percent of all eating and drinking establishments in New Jersey and Pennsylvania.

${ }^{32}$ If we instead use data on December-to-December employment changes, which would eliminate seasonal differences between the fast-food and non-fast-food components of the restaurant industry, the New Jersey-Pennsylvania employment growth differences over 1992 are -0.7 for the BLS-790 data, 0.1 for the ES-202 total state data, and 1.1 for the ES-202 data restricting the Pennsylvania data to the counties covered by CK's data. Thus, in this case the more reliable BLS-790 data indicate slower employment growth in New Jersey. But in our view, the apparently large non-fast-food component of the 790 or 202 data renders any comparison between the BLS data and the fast-food data (from either source) largely irrelevant.
} 
where such effects might be expected. A better test than a simple comparison of employment growth for one year is one that allows for state-specific differences in employment growth. A simple version of this test comes from comparing the difference in employment growth between New Jersey and Pennsylvania in 1992 with the differences in the surrounding years. In particular, for each of the three data series in panel A of Table 7, the differential between New Jersey and Pennsylvania employment growth was lower in 1992 than in either 1991 or 1993, suggesting that New Jersey's increase in the minimum wage slowed relative employment growth in this sector. ${ }^{33}$

We also subjected the BLS-790 data to a more formal test by regressing the annual percent change in employment in each state from 1982 to 1994 on the percent change in the minimum wage level in each state/year, in a regression including a constant and a dummy variable for New Jersey. ${ }^{34}$ These results are shown in Table 8 . In the first column, where we use annual observations on the February-to-November employment change in each state, the estimated coefficient on the minimum wage variable indicates a negative effect, although it is not statistically significant. In the second column we use December-to-December changes, which remove the seasonal variation in the data. In this case, the estimated coefficient on the minimum wage variable is negative $(-0.21)$ and statistically significant, and indicates an elasticity very close to what we obtain from the fast-food employment data.

${ }^{33} \mathrm{CK}$ 's statistical experiment, by focusing on employment growth over a single period, precludes an analysis of this type, a point emphasized by Hamermesh (1995).

${ }^{34}$ This analysis is not possible with the ES-202 data, owing to a break in the series in January 1991. In particular, a one-time improvement in the method of reporting led to a large downward correction to the universe employment counts for establishments using payroll processing firms. Historical adjustments were made to the BLS-790 data to account for this correction; however, no historical revisions were made to the ES-202 data (American Statistical Association, 1993). 
Thus, in our view the BLS data on employment at eating and drinking places neither confirm nor reject our findings from the payroll data that the New Jersey minimum wage increase reduced fast-food employment. The BLS data do, however, provide complementary evidence that minimum wage increases reduce employment in the restaurant industry.

\section{Conclusions}

This paper describes our re-evaluation of Card and Krueger's findings from the New Jersey-Pennsylvania minimum wage study, using data from actual payroll records for a sample of fast-food restaurants that overlaps extensively with CK's sample. Our analysis of these payroll data reveals two findings. First, the data collected by CK indicate much higher variation of employment change than is observed in the payroll data. Second, whereas CK's data imply that the New Jersey minimum wage increase led to an employment increase in New Jersey relative to the Pennsylvania control group, our preferred differences-in-differences estimate using the payroll data implies that the minimum wage increase led to a statistically significant 4.6 percent decline in employment in New Jersey relative to the Pennsylvania control group, or an elasticity of -0.24 . A variety of sensitivity analyses of this result yield estimated elasticities ranging from -0.18 to -0.27 , with the estimated disemployment effects statistically significant at the five- or ten-percent level. Thus, the payroll data raise doubts regarding the quality of the telephone survey data collected by CK, and indicate, contrary to CK's conclusion, that New Jersey's minimum wage increase had a negative effect on employment. 


\section{$\underline{\text { References }}$}

American Statistical Association. 1993. Report from ASA Panel on the Bureau of Labor Statistics Current Employment Survey.

Brown, Charles, Curtis Gilroy, and Andrew Kohen. 1982. "The Effect of the Minimum Wage on Employment and Unemployment. " Journal of Economic Literature, Vol. 20, No. 2, pp. 487-528.

Card, David, and Alan B. Krueger. 1994. "Minimum Wages and Employment: A Case Study of the Fast-Food Industry in New Jersey and Pennsylvania." American Economic Review, Vol. 84, No. 4, pp. 772-793.

Hamermesh, Daniel S. 1995. "Myth and Measurement: The New Economics of the Minimum Wage, Comment by Daniel S. Hamermesh, "What a Wonderful World This Would Be". " Industrial and Labor Relations Review, Vol. 48, No. 4, pp. 835-838.

Lavin, James. 1995. "Evaluating the Impact of Minimum Wages on Employment: Endogenous Demand Shocks in the Fast Food Industry." Mimeograph, Stanford University.

Neumark, David, and William Wascher. 1992. "Employment Effects of Minimum and Subminimum Wages: Panel Data on State Minimum Wage Laws." Industrial and Labor Relations Review, Vol. 46, No. 1, pp. 55-81.

Welch, Finis. 1995. "Myth and Measurement: The New Economics of the Minimum Wage, Comment by Finis Welch." Industrial and Labor Relations Review, Vol. 48, No. 4, pp. 842-849. 
Descriptive Statistics By State

Mean Std. dev. Max./Min. $\begin{gathered}90 \text { th } / 10 \text { th } \\ \text { centile }\end{gathered}$

(1)

(2)

(3)

(4)

10.8

8.4
$22.8 /-41.5$
$34 /-34$

8.4

$34 /-34$
$11.8 /-17.5$
$10.5 /-8$
74
304

2.78

0.70

$\underline{\text { Regression Estimates }}$

NJ-PA

employment

change

(6)

$\underline{\text { Elasticity }}$

(5)

\section{B. Card/Krueger full sample, non-management FTE's}

Change in non-management

\section{FTE's}

Pennsylvania

$\begin{array}{ll}-2.3 & 10.7\end{array}$

New Jersey

.59

8.2

23.8/-43.5

10.2/-17.7 75

2.94

$10 /-7.5 \quad 310$

(1.13)

0.88

\section{Card/Krueger restaurants} in sampled universe:

Change in non-management

\section{FTE's}

Pennsylvania

$-3.0$

0.90

13.2

$23.8 /-43.5$

$15.1 /-19.3$

38

171

3.39

0.93

(1.81)

$35 /-25.5 \quad 10.9 /-6.9 \quad 171 \quad(1.81)$

(2.93

\section{Card/Krueger restaurants in nonsampled universe:}

Change in non-management

FTE's

Pennsylvania

New Jersey

$\begin{array}{cc}-1.6 & 7.5 \\ .22 & 7.8\end{array}$

$16 /-20$

$21.5 /-34$

$5.6 /-14.5$

37

$8.3 /-8.5$

139

1.62

0.54

"FTE's" refers to full-time equivalent employees. The "sampled universe" is Burger King and KFC franchises, and Wendy's and Roy Rogers franchises and company-owned restaurants, in the zip code areas listed in Table 3. Samples include all establishments open for both the first and second interviews. Estimates in column (6) are from a regression of employment change on a dummy variable for New Jersey, and dummy variables for chains and company-owned units. Standard errors are reported in parentheses. Elasticities in column (7) are evaluated at sample means for the corresponding sample. 


$\begin{array}{llllllll}\text { BK } & \text { BK } & \text { RR } & \text { RR } & \text { Wendy's Wendy's } & \text { KFC } & \text { KFC }\end{array}$

franchise company $\underline{\text { franchise }}$ company $\underline{\text { franchise }}$ company $\underline{\text { franchise }}$ company
(1)
(2)
(3)
(4)
(5)
(6)
(7)
(8)

A. Card/Krueger

full sample

Restaurants in

Card/Krueger data:

Pennsylvania

New Jersey

$34 \quad 0 \quad 4$

4
25

12

7

$51 \quad 36$

$\begin{array}{lcc}6 & 4 & 8 \\ 4 & 40 & 28\end{array}$

Zip code areas in

Card/Krueger data:

Pennsylvania

$10 \quad 0$

23

3

4

13

33

New Jersey

20

10

10

16

15

3

B. Card/Krueger sampled universe

Restaurants in

$\underline{\text { Card/Krueger data: }}$

Pennsylvania

20

92

12

46

0

6

0

13

0

New Jersey

Zip code areas in

Card/Krueger data:

Pennsylvania

New Jersey

0

3

0

3

$\begin{array}{ll}0 & 0 \\ 4 & 0\end{array}$

\section{Payroll data}

Restaurants in

payroll data:

Pennsylvania

31

63

$\begin{array}{ll}0 & 0 \\ 0 & 7\end{array}$

31

0

64

15

9

$\begin{array}{cc}0 & 0 \\ 10 & 0\end{array}$

Zip code areas in

payroll data:

$$
\text { Pennsylvania }
$$

New Jersey$$
5
$$

5

14

0
2

3

13

0
4

3

$\begin{array}{lll}3 & 0 & 0 \\ 0 & 4 & 0\end{array}$

Samples include all establishments open for both the first and second interviews. "Zip code areas" refers to first three digits of zip code. 
Card/Krueger Data

$\begin{array}{cccc}\begin{array}{c}\text { Mean change } \\ \text { in FTE's }\end{array} & \begin{array}{l}\text { Standard } \\ \text { deviation }\end{array} & \begin{array}{c}90 \text { th/10th } \\ \text { centile }\end{array} & \text { Obs. }\end{array}$

\section{A. Zip code areas}

(2)
(3)

(4) with payroll data on all units:

\section{Burger King \\ franchises:}

Pennsylvania

(189)

New Jersey

$(088,086,072)$

$-11.3$

4.3

Wendy's franchises:

New Jersey

(088)

Wendy's

company-owned:

Pennsylvania

$(194,181,180)$

Roy Rogers company-owned:

Pennsylvania $(194,190,189)$

New Jersey $(088,085,084,081$, $080,079,078,077$. 076,074,073,071, 070)

Total

Pennsylvania

New Jersey

$$
-4.8
$$

0.3

8.0

6.9

\section{9/-18.9}

$11 /-6.5$

20

62

\section{B. Zip code areas} with payroll data

on some units:

Burger King

franchises:

Pennsylvania

$(194,190,186,182)$

New Jersey

$\begin{array}{cccc}\begin{array}{c}\text { Mean change } \\ \text { in FTE's }\end{array} & \begin{array}{c}\text { Standard } \\ \text { deviation }\end{array} & \begin{array}{c}\text { 90th/10th } \\ \text { centile }\end{array} & \text { Obs. }\end{array}$

8)
Pavroll Data

(6)

(7)
4

15

8 9 31 64 87
$-1$.

17.3

$19.7 /-31.4$

2.9

1.9

$5.5 / 0.6$

27

$\begin{array}{llll}0.9 & 9.5 & 10.5 /-14 & 80\end{array}$

2.0

1.7

$4.5 /-0.3$

48 New Jersey $080,079,078,076$, $074,073,071,070$ )

Wendy's franchises:

New Jersey

6.2

13.2

$33.8 /-6.5$

10

0.9

5.8

$7.1 /-10.5$

7 
Card/Krueger Data

\begin{tabular}{|c|c|}
\hline $\begin{array}{l}\text { Mean change } \\
\text { in FTE's }\end{array}$ & $\begin{array}{l}\text { Standard } \\
\text { deviation }\end{array}$ \\
\hline
\end{tabular}

(1)

(2)

(3)

3.0

4.9

$11.5 /-1.5$

6

Obs.

(4)

Roy Rogers

New Jersey

$(086,085)$

KFC franchises:

New Jersey

$(086,085,080,076)$

3.7

$5 /-6.1$

13

$-4.0$

4.3

$0.7 /-11.3$

10

Total

Pennsylvania

$$
-1.1
$$

17.3

9.3

$19.5 /-31.4$
$10.5 /-8$

18

109

2.9

0.8

1.9

3.5

$5.5 / 0.6$

$4.6 /-3.5$

27

72

\section{All sampled}

zip code areas:

Pennsylvania

\& New Jersey

0.2

9.6

$11 /-10$

209

0.3

3.2

$4.4 /-3.5$

230

We cannot match up data establishment by establishment within each chain/zip code cell, because we cannot identify individual establishments in the Card/Krueger data. FTE's in the Card/Krueger data are the number of non-management full-time workers plus one-half of the number of non-management part-time workers. FTE's in the payroll data are total non-management hours divided by 35. Card and Krueger's initial survey was taken over the period Feb. 15-March 4, 1992, and the second was taken over the period Nov. 5-Dec. 31, 1992. Because we cannot match establishments across the two data sources, and because CK's data set does not include interview dates for the first wave, we obtained records for as many payroll periods as possible within these dates. For the payroll data, we have data on one to four payroll periods that fall within this period. We randomly selected one payroll period. Payroll data are reported either weekly, bi-weekly, or monthly. The monthly reports refer to February or November. We divided hours reported by 2 for bi-weekly reports. For the Burger King franchises supplying monthly reports, the figures refer to total hours worked in the month. Therefore, to arrive at a consistent weekly hours number, we divide monthly hours by $29 / 7$ for February (1992 was a leap year), and by 30/7 for November. The Roy Rogers company data were also reported as monthly, but actually refer to hours worked in a four-week period. Thus, for these restaurants we simply divide by four. 
Figure 1--Employment Levels and Changes in the Two Data Sources, Restaurants in Chain/Zip Codes/Ownership Cells with Complete Data

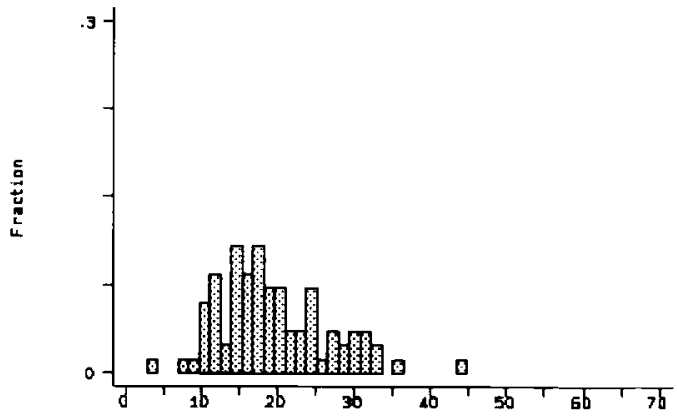

Nave 1 Employment, Card/Krueger Data

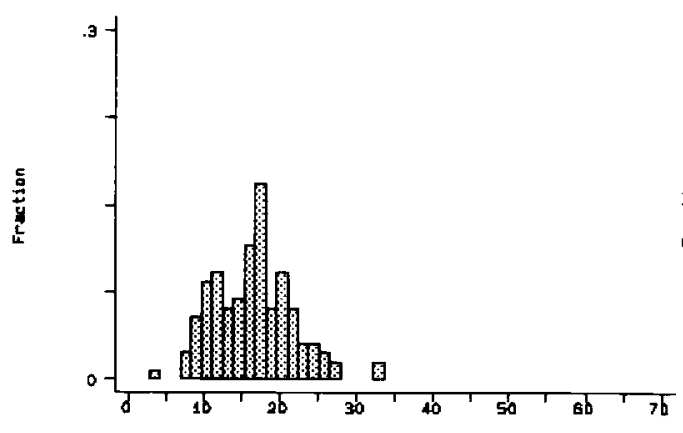

Wave 1 Enployment, Payroll Oato

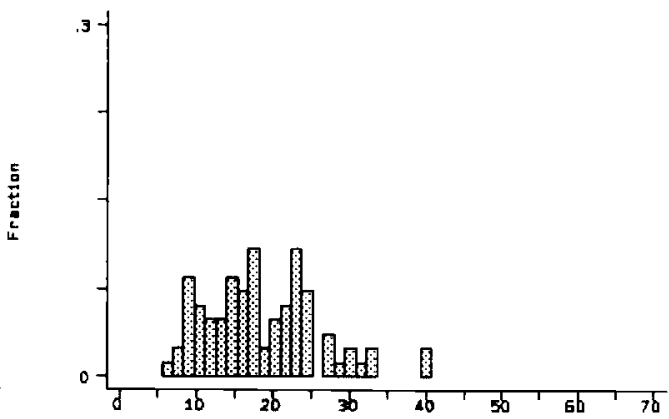

Nave 2 Employnent, Card/Krueger Data

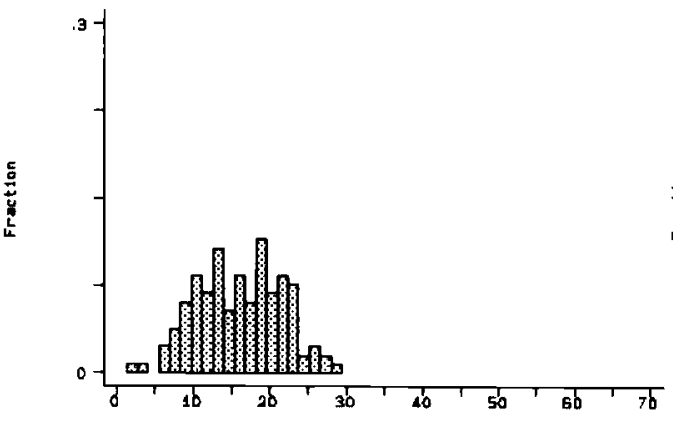

Wave 2 Enployment, Payroll Data

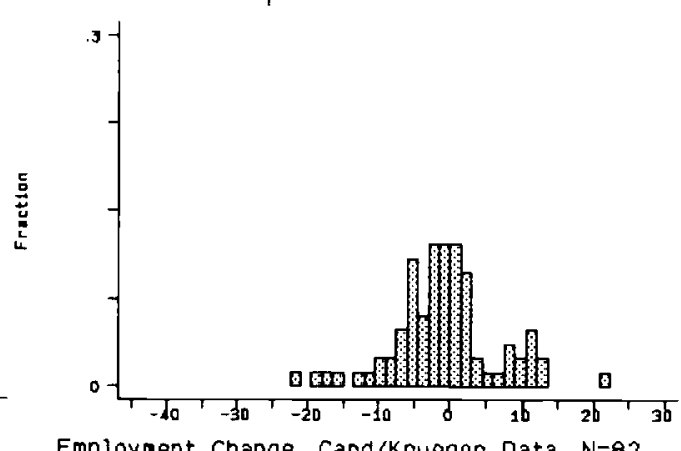

Employnent Change, Caro/krueger Data, $\mathrm{N}=82$

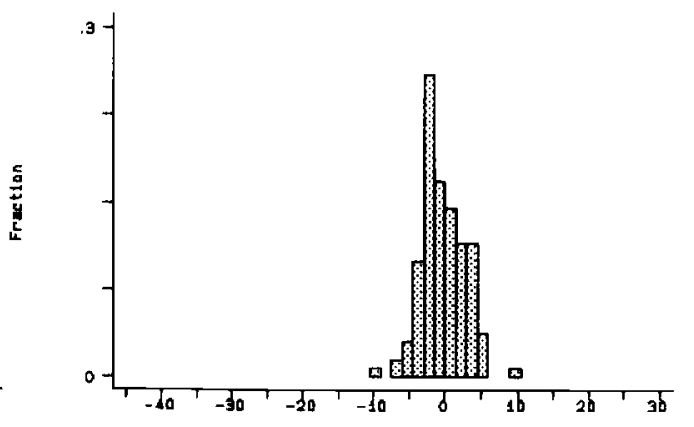

Employment Change, Payrall Data, $N=131$ 
Figure 2--Employment Levels and Changes in the Two Data Sources, Payroll Data and Sampled Universe in Card/Krueger Data

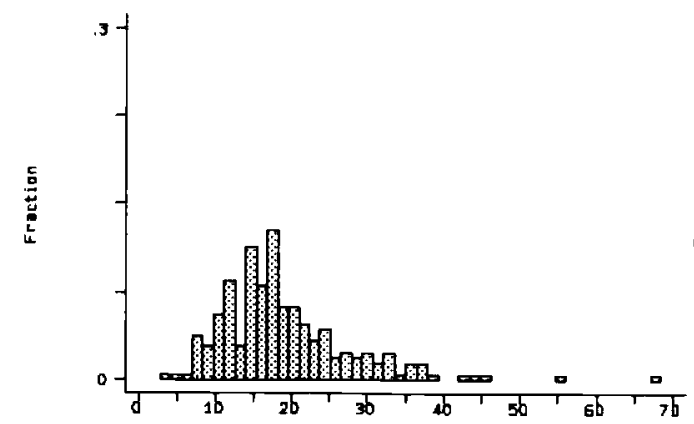

Wave 1 Employnent, Card/krueger Data

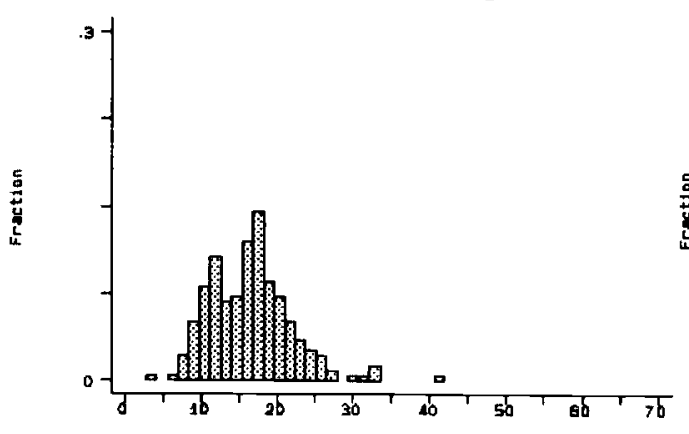

Wave 1 Enployment, Payrall Data
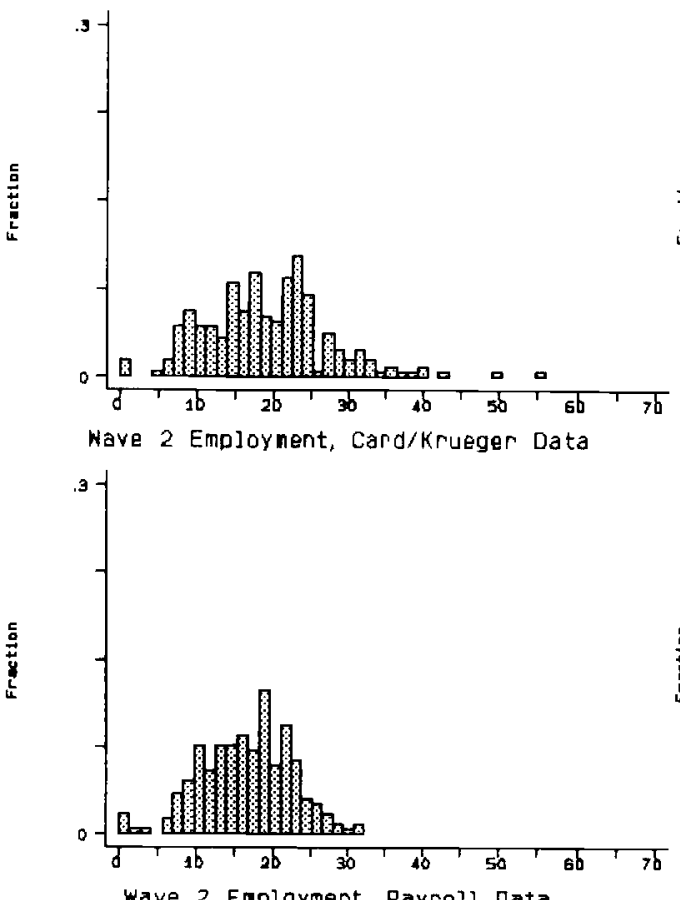

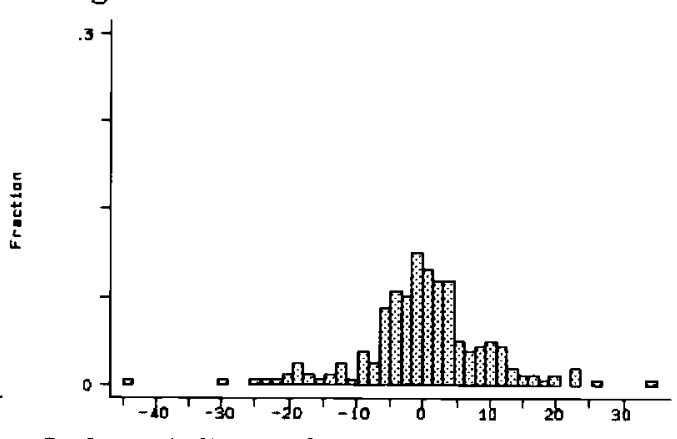

Enployment Change, Card/Krueger Data, $N=209$

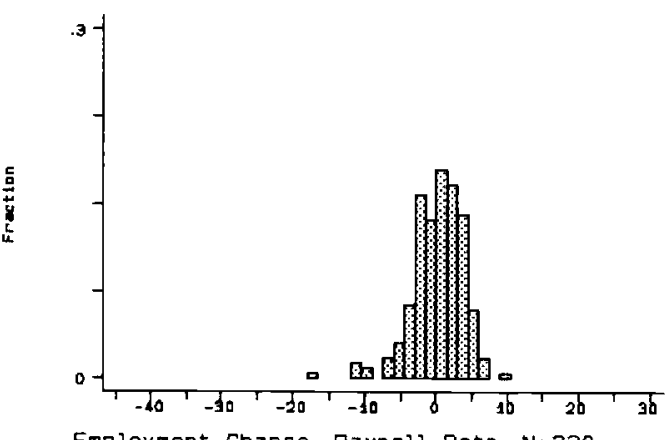


Table 4: Card/Krueger Data vs. Payroll Data, Differences-in-Differences Estimates of Minimum Wage Effects on Non-Management Employment, Burger King and KFC Franchises, and Wendy's and Roy Rogers Franchises and Company-Owned Restaurants

\begin{tabular}{|c|c|c|c|c|c|c|}
\hline \multirow[b]{3}{*}{ Card/Krueger data: } & \multicolumn{2}{|c|}{$\begin{array}{c}\begin{array}{c}\text { Estimate of minimum } \\
\text { wage effect on relative } \\
\text { employment in New Jersey: }\end{array}\end{array}$} & \multirow[b]{2}{*}{$\begin{array}{l}\text { Implied } \\
\text { elasticity }\end{array}$} & \multirow[b]{2}{*}{$\begin{array}{l}\text { Percentage } \\
\frac{\text { effect }}{(4)}\end{array}$} & \multirow[b]{2}{*}{$\begin{array}{l}\text { Number of } \\
\text { observations }\end{array}$} & \multirow[b]{2}{*}{$\frac{\text { Adj. }-R^{2}}{(6)}$} \\
\hline & $\begin{array}{c}\text { Differences-in } \\
\text { differences } \\
(1)\end{array}$ & $\frac{\text { Regression }}{\text { (2) }}$ & & & & \\
\hline & $\begin{array}{c}3.18 \\
(1.48)\end{array}$ & $\begin{array}{c}3.15 \\
(1.27)\end{array}$ & 0.90 & $16.9 \%$ & 325 & 0.016 \\
\hline $\begin{array}{l}\text { Card/Krueger data, } \\
\text { sampled zip code areas only: }\end{array}$ & $\begin{array}{c}3.92 \\
(2.27)\end{array}$ & $\begin{array}{c}3.39 \\
(1.81)\end{array}$ & 0.93 & $17.6 \%$ & 209 & 0.035 \\
\hline Payroll data: & $\begin{array}{l}-0.98 \\
(0.44)\end{array}$ & $\begin{array}{l}-0.75 \\
(0.37)\end{array}$ & -0.24 & $-4.6 \%$ & 230 & 0.433 \\
\hline $\begin{array}{l}\text { Payroll data, using } \\
\text { averages of payroll } \\
\text { records: }\end{array}$ & $\begin{array}{l}-0.92 \\
(0.42)\end{array}$ & $\begin{array}{l}-0.76 \\
(0.34)\end{array}$ & -0.24 & $-4.6 \%$ & 230 & 0.483 \\
\hline
\end{tabular}

See notes to Table 1. The regression estimate is from a regression of the change in employment on an intercept, a dummy variable for New Jersey, and dummy variable for chain and company-owned units. The elasticities and implied effects in columns (3) and (4) are computed at the sample means, using the regression estimates. 
Table 5: Card/Krueger Data vs. Payroll Data, "Wage Gap" Estimates of Minimum Wage Effects on Non-Management Employment, Burger King and KFC Franchises, and Wendy's and Roy Rogers Franchises and Company-Owned Restaurants

\begin{tabular}{|c|c|c|c|c|c|}
\hline & $\frac{\text { Wage gap }}{\text { (1) }}$ & $\begin{array}{l}\text { Wage gap using } \\
\text { mean starting wage } \\
\frac{\text { in zip code area }}{(2)}\end{array}$ & $\begin{array}{c}\text { New Jersey } \\
\text { dummy variable }\end{array}$ & $\begin{array}{l}\text { Implied } \\
\text { elasticity } \\
(4)\end{array}$ & $\begin{array}{c}\begin{array}{c}\text { Number of } \\
\text { observations }\end{array} \\
\text { (5) }\end{array}$ \\
\hline Card/Krueger data: & $\begin{array}{l}22.3 \\
(7.2)\end{array}$ & $\ldots$ & $\ldots$ & 0.72 & 281 \\
\hline $\begin{array}{l}\text { Card/Krueger data, } \\
\text { sampled zip code areas: }\end{array}$ & $\begin{array}{l}23.3 \\
(9.1)\end{array}$ & $\ldots$ & $\ldots$ & 0.73 & 199 \\
\hline \multirow{3}{*}{$\begin{array}{l}\text { Payroll data, } \\
\text { using averages: }\end{array}$} & $\ldots$ & $\begin{array}{c}27.4 \\
(13.0)\end{array}$ & $\cdots$ & 0.85 & 199 \\
\hline & $\ldots$ & $\begin{array}{l}-3.8 \\
(2.6)\end{array}$ & $\cdots$ & -0.13 & 221 \\
\hline & $\cdots$ & $\begin{array}{c}4.5 \\
(4.7)\end{array}$ & $\begin{array}{l}-1.23 \\
(0.60)\end{array}$ & -0.24 & 221 \\
\hline
\end{tabular}

See notes to Table 1. The mean wage gap is calculated from the Card/Krueger data by zip code area using the appropriate sample. The sample is smaller for CK's data because the starting wage had to be available. The elasticity is evaluated at the sample means of the starting wage (or the mean starting wage in the zip code area calculated from the Card/Krueger data) and the employment level for New Jersey. All regressions also include dummy variables for the restaurant chain and company-owned units. Standard errors of the regression estimates are reported in parentheses. 
Table 6: Card/Krueger Data vs. Payroll Data, Differences-in-Differences Estimates of Minimum Wage Effects on Non-Management Employment, Sensitivity Analysis

\begin{tabular}{|c|c|c|c|c|c|}
\hline \multirow{3}{*}{$\begin{array}{l}\text { A. Including all closed } \\
\text { restaurants }\end{array}$} & \multicolumn{2}{|c|}{$\begin{array}{c}\text { Estimate of minimum } \\
\text { wage effect on relative } \\
\text { employment in New Jersey: }\end{array}$} & \multirow[b]{2}{*}{$\begin{array}{l}\text { Implied } \\
\text { elasticity } \\
(3)\end{array}$} & \multirow[b]{2}{*}{$\begin{array}{l}\begin{array}{l}\text { Number of } \\
\text { observations }\end{array} \\
(4)\end{array}$} & \multirow[b]{2}{*}{$\frac{\text { Adj. }-R^{2}}{(5)}$} \\
\hline & $\begin{array}{l}\text { Differences-in } \\
\text { differences } \\
\text { (1) }\end{array}$ & $\frac{\text { Regression }}{(2)}$ & & & \\
\hline & & & & & \\
\hline $\begin{array}{l}\text { Card/Krueger data, } \\
\text { sampled universe: }\end{array}$ & $\begin{array}{l}3.76 \\
(2.27)\end{array}$ & $\begin{array}{c}3.21 \\
(1.80)\end{array}$ & 0.89 & 212 & 0.036 \\
\hline $\begin{array}{l}\text { Payroll data, using } \\
\text { averages: }\end{array}$ & $\begin{array}{l}-0.88 \\
(0.50)\end{array}$ & $\begin{array}{l}-0.70 \\
(0.41)\end{array}$ & -0.23 & 235 & 0.401 \\
\hline \multicolumn{6}{|c|}{$\begin{array}{l}\text { restaurants common to } \\
\text { zip code areas and chains } \\
\text { in both data sources }\end{array}$} \\
\hline $\begin{array}{l}\text { Card/Krueger data, } \\
\text { sampled universe: }\end{array}$ & $\begin{array}{c}3.81 \\
(2.27)\end{array}$ & $\begin{array}{l}3.26 \\
(1.80)\end{array}$ & 0.90 & 211 & 0.037 \\
\hline $\begin{array}{l}\text { Payroll data, using } \\
\text { averages: }\end{array}$ & $\begin{array}{l}-1.00 \\
(0.42)\end{array}$ & $\begin{array}{l}-0.83 \\
(0.34)\end{array}$ & -0.27 & 232 & 0.485 \\
\hline \multicolumn{6}{|l|}{$\frac{\text { C. Percent change }}{\text { specification }}$} \\
\hline $\begin{array}{l}\text { Card/Krueger data, } \\
\text { sampled universe: }\end{array}$ & $\begin{array}{c}0.182 \\
(0.091)\end{array}$ & $\begin{array}{c}0.165 \\
(0.083)\end{array}$ & 0.88 & 209 & 0.045 \\
\hline $\begin{array}{l}\text { Payroll data, using } \\
\text { averages: }\end{array}$ & $\begin{array}{l}-0.061 \\
(0.026)\end{array}$ & $\begin{array}{l}-0.034 \\
(0.020)\end{array}$ & -0.18 & 230 & 0.496 \\
\hline \multicolumn{6}{|l|}{$\begin{array}{l}\text { D. Weighted to represent } \\
\text { restaurants in CK's } \\
\text { sampled universe }\end{array}$} \\
\hline $\begin{array}{l}\text { Payroll data, using } \\
\text { averages: }\end{array}$ & $\begin{array}{l}-0.94 \\
(0.41)\end{array}$ & $\begin{array}{l}-0.84 \\
(0.40)\end{array}$ & -0.27 & 230 & 0.483 \\
\hline $\begin{array}{l}\text { E. Random effects } \\
\text { estimates, changes } \\
\text { in employment levels }\end{array}$ & & & & \multicolumn{2}{|c|}{$\begin{array}{l}\text { LM test for random } \\
\text { effects (p-value) }\end{array}$} \\
\hline $\begin{array}{l}\text { Payroll data, } \\
\text { using averages: }\end{array}$ & $\ldots$ & $\begin{array}{l}-0.64 \\
(0.39)\end{array}$ & -0.20 & 228 & 0.90 \\
\hline
\end{tabular}

See notes to Tables 1 and 4 . The percent change in employment is calculated relative to the initial employment level, and the regression estimates are weighted by the initial employment level. For the random effects estimation, two observations are dropped because two franchisees own single restaurants in the sample. 


\section{A. BLS data}

\begin{tabular}{|c|c|c|c|c|c|c|}
\hline \multirow[b]{2}{*}{ Year } & \multicolumn{3}{|c|}{$\begin{array}{c}\text { BLS-790, } \\
\begin{array}{c}\text { February-November, } \\
\text { total state }\end{array} \\
\end{array}$} & \multicolumn{3}{|c|}{$\begin{array}{c}\text { ES-202, } \\
\text { February-November, } \\
\text { total state }\end{array}$} \\
\hline & $\underline{\mathrm{NJ}}$ & PA & Diff & $\underline{\mathrm{NJ}}$ & PA & Diff \\
\hline 1991 & 6.3 & 3.8 & 2.5 & $4 . \overline{9}$ & 4.0 & 0.9 \\
\hline 1992 & 6.8 & 6.0 & 0.8 & 5.9 & 6.2 & -0.3 \\
\hline 1993 & 5.8 & 4.3 & 1.5 & 5.9 & 4.5 & 1.4 \\
\hline 1994 & 10.6 & 5.5 & 5.1 & $\ldots$ & $\ldots$ & $\ldots$ \\
\hline
\end{tabular}

B. Card/Krueger data

Card/Krueger data, total employment

1992 FTE's

$2.3 \frac{\text { NJ }}{2.3} \quad-9.8 \quad \underline{\text { PA }} \quad \frac{\text { Diff. }}{12.1}$

Employees
Card/Krueger data, non-management employment

$\begin{array}{rrr}\underline{\mathrm{NJ}} & \underline{\mathrm{PA}} & \underline{\text { Diff. }} \\ 2.7 & -12.4 & 15.1 \\ 0.8 & -7.5 & 8.3\end{array}$

ES-202,

February-November, total NJ, PA counties in Card/Krueger's data

$\begin{array}{lll}\frac{\mathrm{NJ}}{9} & \frac{\mathrm{PA}}{3.2} & \frac{\text { Diff. }}{1.7}\end{array}$

$\begin{array}{lll}5.9 & 5.1 & 0.8\end{array}$

$\begin{array}{lll}5.9 & 4.5 & 1.4\end{array}$

\section{Payroll data, using averages}

Card/Krueger data, non-management employment, sampled universe

$\begin{array}{rrr}\underline{\mathrm{NJ}} & \underline{\mathrm{PA}} & \underline{\text { Diff. }} \\ 4.0 & -13.4 & 17.5 \\ 1.3 & -9.6 & 10.8\end{array}$

1992 FTE's

Payroll data

$\begin{array}{lll}\stackrel{\text { NJ }}{-0.6} & \underline{\text { PA }} & \underline{\text { Diff. }} \\ -5.1 & -5.8\end{array}$

Percentage employment growth across all establishments is reported. 
Table 8: Regression Estimates of Minimum Wage Effects on Employment Growth Rate, Using BLS-790 Data,

Eating and Drinking Places in New Jersey and Pennsylvania

\begin{tabular}{lcc}
\hline Variable & $\begin{array}{c}\text { Percent change } \\
\text { February to November }\end{array}$ & $\begin{array}{c}\text { Percent change } \\
\text { December to December }\end{array}$ \\
\cline { 2 - 3 } $\begin{array}{l}\text { Minimum wage } \\
\text { (percent change) }\end{array}$ & -0.15 & -0.21 \\
New Jersey & $(0.10)$ & $(0.09)$ \\
& 0.27 & 0.11 \\
Constant & $(1.09)$ & $(0.93)$ \\
& 6.60 & 2.33 \\
$\mathrm{R}^{2}$ & $(0.80)$ & $(0.67)$ \\
& 0.08 & 0.20 \\
\hline
\end{tabular}

The sample period is 1982-1994. The results were insensitive to correcting for first-order serial correlation. 